Chapter 15

\title{
15 Teaching and learning content through two languages: The biology and history teacher perspective \\ Ylva Sandberg
}

\section{Introduction}

The present qualitative study focuses biology and history teachers' reflections on language practices in CLIL. Building on theory from teacher cognition, subject-content didactics and bilingual education, the study aims to document and interpret eight teachers' motivations to language use and teaching in the bilingual CLIL strand at their school. The study encompasses semi-structured interviews with teachers at three different upper secondary schools, four biology and four history teachers, and the data were collected over a two-year period. The analyses were thematic and adopted a constant comparative approach. Overall, findings show that English and Swedish co-exist as resources for teaching and learning in CLIL biology and history. More specifically, teachers' motivations to language use could be related to two themes: access to study material and adaptation to student group. Following a discussion of the results, the study concludes with recommendations for teaching and implications for further research.

\section{Background}

Through a CLIL framework teachers and learners have access to two languages in daily classroom practice (Dalton-Puffer, 2011). In comparison with mainstream study programs where officially one language of schooling functions as only language for teaching curriculum content, participants in CLIL strands formally act in a bilingual space. The expectations of participants involved in these programs are that they manage to learn and teach content through two languages.

Managing the learning and teaching of content through two languages is not uncomplicated. With CLIL comes a dual focus on content and language (Coyle, Hood \& Marsh, 2010, authors' highlighting). For the content teacher used to traditional teaching in the contentbased classroom, CLIL teaching means integrating knowledge and practices from the languagebased classroom into the content-based classroom (Lundahl, 2010). However, this "does not mean adopting the role of a language teacher" (Coyle, Hood \& Marsh, 2010, p. 10). It means integrating the teaching of content with the teaching of language (Cross, 2016, author's higlighting), in the bilingual space (Dalton-Puffer, 2011). In this process, decisions for teaching and learning need to be made with regard to the syllabi for the specific school subjects, e.g. biology and history.

A good twenty years ago, with the implementation of the 1994 curriculum for the Swedish upper secondary school, Lpf 94 (Skolverket [The Swedish National Agency of Education], 1994), it became possible for upper secondary schools to develop local study programs. During this time, a growing number of upper secondary schools developed bilingual study programs (Nixon, 2001). Several of these schools with an international profile, or CLIL strands, still exist today in various parts of Sweden (Yoxsimer Paulsrud, 2014). 
Despite the quantity and diversity of bilingual, or CLIL, teaching experiments in the Swedish educational context, relatively few research studies have been carried out in the field, which is surprising. Indeed, "[i]ntroducing CLIL as a method of language teaching should not be based on guesswork, fashionable political ideas or potential gains for a particular school. It should all be for the benefit of the student" (Sylvén, 2013, p. 316). With regard to the study of CLIL practitioners' reflections on language practices it is not until recently that a research focus has gained momentum (Lim Falk, 2008; Yoxsimer Paulsrud, 2014, Sandberg, 2015). The aim of this study is to investigate biology and history teachers' interpretations of the Swedish-English bilingual space afforded by CLIL at their schools. The research question has been formulated as follows:

- What are upper secondary biology and history teachers' motivations to language use and teaching in CLIL?

\section{Theoretical framework}

To frame this study, concepts from teacher cognition, subject-content didactics and bilingual education have been chosen. In particular, the metaphor of the teacher as reflective practitioner, the concept of subject-specific literacies and the aspect of languaging have been applied. In addition, the term CLIL teaching literacy was developed by the researcher.

\subsection{Teacher cognition}

Teacher cognition research takes an interest in the factors, conditions and principles that guide the professional thinking of teachers, and demonstrates that these processes are often highly complex (Borg, 2006). In earlier seminal work on teacher thinking, the notions of the teacher as 'reflective practitioner' (Argyris \& Schön, 1974) and the conceptualization of pedagogic content knowledge, PCK, (Shulman, 1986) underscore this complexity. Whereas Argyris \& Schön show that teaching is the result of continuous reflection on the part of the teacher, Shulman highlights the pedagogic dimension of content knowledge, i.e. that content knowledge per se and the teaching of content knowledge are epistemologically different. Both Argyris \& Schön's and Shulman's insights are crucial to understanding teacher professional development.

In long term and short term perspectives, teachers consider factors potentially impacting their teaching, e.g. national curriculum documents, local school policies, interaction with colleagues and students, personal teaching experience, personal learning experiences, as well as beliefs and perspectives in general. For CLIL content teachers, two languages of schooling become part of daily practice, decision-making and reflection.

Acting as a teacher in the CLIL space means being in charge of "the planned, systematic meshing of language teaching with the teaching of content" (Nixon, 2001, p.225), the definition of 'content' being 'any subject content that is not a language' (ibid). In the CLIL teachers' planning for teaching, in-teaching decisions, and in their reflections after teaching, they "need to adapt subject-specific methods to accommodate the additional language focus" (Coyle, Hood \& Marsh, 2010, p. 10). Rather than viewing the content teacher as a language teacher per se, it means developing a different mind-set and trying to "open doors for alternative ways of using methodologies which can be rewarding for both the teachers and the learners" (ibid). It is what this article aims to explore and document: biology and history teachers' encounters with two languages of schooling. 


\subsection{Subject-content didactics}

As part of a growing field of research in the Nordic countries on subject-content didactics (e.g. Schüllerqvist, 2012), of which language education (Tornberg, 2009) forms a part, studies on teachers' professional thinking as part of teaching specific subjects have become a matter of interest.

Relevant to this study is the development of the term 'disciplinary literacy' (Airey 2013, p. 41), responding to a need of a more specific term to encompass the practices and discourses within a specific academic discipline in tertiary education. Considering scientific literacy to be too broad a term, Airey (2013) claimed that disciplinary literacy more precisely captures what students need to be able to do and to know within the specific academic discipline. Similarly, the concept of subject-specific literacy (Gibbons 2009) or the term school subject literacy could be suitable to encompass and target the requirements in the new curriculum for upper secondary school for what students need to know, do and reflect on in a specific school subject, e.g. biology or history.

Biology is a core subject in the natural sciences program. In the syllabus for biology, it is stated that "the contexts and connections related to biology are often complex and being studied at different levels, from the molecular unit to global ecosystems" (Lgy 2011, Biology). From a language education point of view, this indicates study of content through advanced subjectspecific language, e.g. nominal phrases and verbs denoting processes and relations (Halliday, 2004; Halliday \& Mathiessen, 2004). It is also evident that the syllabus text is focused on students' active participation, for example through the following expressions: "The student describes and generalizes about connections... The student formulates hypotheses ... discusses ... motivates their conclusions with well-founded arguments" (Lgy, 2011, Biology). Obviously, there is an emphasis not only on learning about science, but on doing science (Lemke, 2000). The students have to engage with many activities in biology, activities which are mediated through language.

History is a core subject in the social sciences program. In the syllabus for history it is stated that students should learn to work with historical method, i.e. "search, assess, interpret, and evaluate different sources as well as use different theories, perspectives and tools that explain and visualize historical developmental processes" (Lgy 2011, p. 66). In this way, the syllabus for history emphasizes students' active participation, with a special focus on critical literacy. From a language education point of view, these tasks that students should be able to perform in history class involve advanced linguistic proficiency. In addition, the students should "present the results of their work by means of different expressions, orally as well as in written format, assisted by modern information technology" (ibid).

For the teacher, this means planning teaching and learning in such a way that the students are given space for content and language production through the different modes.

\subsection{Bilingual education}

Bilingual education refers to any formal environment where two or more languages are used by the participants (Leung, 2005). At present, bilingual education encompasses a whole range of approaches to the teaching and learning of content through two or more languages (García, 2009).

As a means of describing bilingual programs, and the potential consequences of their implementation, García has made a division of programs into three main groups: subversive, parallel, and multidimensional programs. In the first case, the one language dominates the other 
in language use, in the second, the languages are used separately, and in the third case, languages are used inter-changeably, in a dynamic way (García, 2009, pp. 51-54).

Drawing on extensive research, an increasing number of researchers claim that there is not one single recipe for language practices in bilingual school settings (e.g. García, 2009, 2011). Instead, the key to meaningful and successful bilingual education involves among other things aiming to try to understand teacher thinking and action within a particular context. In doing this it is necessary to take an interest in understanding the local conditions and requirements for learning and teaching (Cross, 2016; García, 2009).

To conceptualise, and also teach, language as part of different formal registers within school subjects, Lindberg's division of vocabulary into three linguistic registers can be useful: colloquial language, school-related language, and subject-specific language (Lindberg, 2006).

As a means to target CLIL practitioners' language proficiency, and plan for teaching language and teaching about language in the content classroom, Cummins' (1979) distinction between Basic Interpersonal Communicative Skills (BICS) and Cognitive Academic Linguistic Proficiency (CALP) can be helpful (see also Chapter xx, this volume).

Taking interest in the development of language awareness, language choice and language use can be understood as typical language used in a certain context by certain speakers for a certain social purpose (Martin, 1985), i.e. at a genre (ibid) or discourse level.

Viewing language through a literacy lens is in alignment with the new literacy-based 2011 curriculum for Swedish upper secondary school. Indeed, in both content-based subjects and language-based subjects (Lundahl, 2010), the students are to learn by doing, and reflect on their practices.

Similarly, as teachers are expected to know, do, and reflect on their practices, it could be concluded that teaching literacy is a term that responds to today's teachers' professional work.

\section{$4 \quad$ The Study}

In the following, the participants and schools of the study, and the methods for data collection and analysis, are presented.

\subsection{Participants and schools}

Eight content teachers participated in this study, four biology teachers (henceforth referred to as bi1, bi2, bi3 and bi4) and four history teachers (henceforth referred to as hi1, hi2, hi3 and h4). They were certified teachers working at local authority-run schools in mid-sized cities in Sweden. More specifically, they were teachers at upper secondary schools offering study programs in the natural and social sciences with an international profile. In the present study these programs were called CLIL strands.

The biology and history teachers' experience of teaching in the CLIL strand at their schools ranged from one year to twenty years. Two of the teachers were new to teaching and to CLIL (bi1, hi1), three teachers were experienced teachers but were relatively new to CLIL teaching (bi2, hi2, hi3) and three teachers had long-term experience with regard to both aspects (bi3, bi4, hi4). The teachers were native speakers of Swedish. The schools and the participating teachers were part of the longitudinal research project Content and Language Integrated Learning in Swedish Schools (CLISS; for details, see Chapter 1, this volume).

One of the biology teachers, bi4, was among the founders of the bilingual program at his/her school in the mid-1990s. The other teachers had joined the CLIL programs at their schools most often in the mid- or late 2000s. None of the teachers had been enrolled in CLIL in- 
service courses. History teacher h3, however, had previous experience from teaching at a school where many students studied Swedish as a second language.

\subsection{Data collection}

The main data collection tool was semi-structured interview. It was chosen for its combination of structure and flexibility (Bryman, 2013). Typically, the interviews were made with one teacher at a time, each interview taking 25-45 minutes. Including both first time interviews and follow-up interviews, each teacher interview material has a scope of 45-60 minutes. The most common practice was that recordings took place after observations of lessons with the teachers. For reasons of limitations of space, however, the lesson observations will not be attended to in this chapter. The collection of the data took place as part of two-day sessions spent at the school, during a two-year period. The interviews were audio-recorded using an mp3 player. Each interview was transcribed in several stages by the researcher, the first stages most often occurring the same day as the interview was recorded.

In total, the recorded interview data with the teachers amounted to 7 hours and 40 minutes. The time that elapsed between the first interview and the follow-up interview was about a year. The interviews were conducted in Swedish. Therefore, the extracts from the interviews presented in this paper have been translated. The translations have been done by the researcher.

At the follow-up interview, the participants could read through, and comment on the transcripts, acknowledging whether they could recognize themselves in the researcher's interpretation. The follow-up session also made it possible for the researcher to probe deeper with regard to some issues that had emerged as unclear, extra important or interesting.

The researcher, attempting to gain insight into the 'emic', or participant perspective (Brinkmann, 2009), has to be aware of the limitations of the interview method: efforts to understand teachers' language choice and language use are always limited to what the participants choose to speak about, and how it is being interpreted (Richards, 2009). Indeed, the interview itself as a cognitive-social event has to be taken into consideration (Brinkmann, 2009). The contextual factors of the interview situation, such as the time and place of the interview, and the potential influence of the interviewer and interviewee on each other's thinking processes and expressions, will potentially impact the outcome of the study.

\subsection{Data analysis}

As is typical of qualitative data analysis, it proceeded continuously, and, indeed, in constant dialogue with the ongoing data collection. The material was coded thematically in sequences where data were compared at three levels, within the interview itself, between interviews, and in relation to theory. This application of a recursive process in analysis has been in earlier work referred to as a constant comparative perspective (Heath \& Street, 2008, p. 32), and the process of coding used has been called open coding (Bryman, 2013).

According to Nikula, Dalton-Puffer \& Llinares, language practices and strategies can be understood at three levels: learning about languaging, learning of languaging and learning through languaging (Nikula, Dalton-Puffer \& Llinares, 2013). The notion of languaging as a verb is appropriate in this context where participants' reflections on language use is in focus. The three-dimensional understanding of language choice and strategies in relation to teaching and learning emerged as a useful framework for analysis, and for writing up the research of the present study (see further 6 Discussion). 


\section{$5 \quad$ Results}

In the biology and history teachers' motivations to language use and teaching, two themes could be identified: access to study materials and adaptation to student group. In the following, these themes will presented and commented with examples from the interview material.

\subsection{Access to study materials}

In the teachers' reflections it became clear that access to study materials had an impact on teachers' choice of language in several ways. The more experienced teachers reported that a lack of study materials in English made it possible for them to compose their own study materials to correspond to the learning goals of the specific course they taught. They spoke of this as a positive challenge. The experienced teachers enjoyed the creative task and found that it made them deepen their knowledge of the subject.

For the new teachers, lack of access to suitable study materials became a tough challenge. They spoke of the time it took them to search for suitable study materials on the Internet, or the time it took them to translate the presentations they already had used in their previous teaching from Swedish into English. In those cases where international text books were available, the new teachers still had to design the materials to suit the courses following the new 2011 curriculum for the upper secondary school, Lgy11 (Skolverket, 2011).

The history teachers spoke of the benefits of using teaching and learning materials in English available through the Internet. One of the history teachers mentioned that the access to study materials in English afforded in the CLIL strand made history education authentic, as it brought "different perspectives, something which is part of the course content" (hi3). Similarly, another history teacher found that teaching history through English enhanced the use of historic method, as it facilitated the teacher's efforts to provide students with experiences of "working like an historian in contemporary times" (hi4). In the descriptions of teaching, continuous use of digital tools was significant:

I usually tell them [the students], 'as you are watching this, take notes, We'll talk about it afterwards'. It is often a ten-minute video clip on YouTube. ... 10 minutes, and then we discuss. 'Okay, what was being said?', 'What was it about?' -So I can see whether they have understood. By these means, there are opportunities to provide support (hi3)

This teacher found access to study materials on the Web enrichening and supportive, as an additional source of input. As the students had chosen to study through English it was not difficult for the teacher to find suitable material.

Even if the majority of the history teachers' narratives from CLIL teaching accounted for positive experiences of using English study materials in class, there were also examples where teachers spoke of feelings of constraints: since the Swedish history course 1b is "more of an overview course" (hi3), "one of the big challenges with teaching through English is the time and effort it takes to select and adapt material from the international textbook to make it match the Lgy11 history course" (hi 2).

The biology teachers' references to study materials in English included text books in English as well as to materials they had to compose themselves. Similar to the history teachers, one biology teacher spoke of possibilities as well as constraints that came with using a text book of an international edition "If you open a Swedish text book it is not as comprehensive. It usually has a more limited scope." (bi1). Despite benefits of comparison between teaching materials, the 
teacher reported of the extra efforts this brought, having to select, and compose materials in such a way that it corresponded to the course core content and the aims of the 2011 biology 1 course..."It is not an easy task ...finding an accurate level" (bi1).

In this endeavor, the biology teacher found students' questions and comments on the comprehensive study materials helpful: "[Students:] There is so much more information in the book. How much are we supposed to learn?" (bi1). In response to students' reactions, the teacher scrutinized the goals of the course, discussed with colleagues, consulted other textbooks, and could in this way design adequate study materials for the course. Reflecting on the process, the teacher found it both demanding and time-consuming. At the same time the teacher could not help but acknowledging that it had contributed considerably to developing his/her pedagogic content knowledge (see Shulman, 1986).

\subsection{Adaptation to student group}

The eight teachers all addressed the need of adapting their use of language both to student groups and to individual students. The adaptation seemed to vary with teaching experience, and with regard to school subject.

The experienced teachers had developed strategies for language use in whole-class format, small group work and with regard to individual students. For example, the teachers would lecture in English only, but they would let the students ask questions in Swedish (hi4, bi2). In response to the needs of individual students, they would use Swedish to explain complex content, in realtime conversation or via email (hi4). In responding to students' questions, the teacher would respond in the same language as the student chose to use (bi2).

The new teachers put extra effort into making their power-point presentations lively and spectacular. Indeed, they spoke of using humoristic pictures and jokes to engage and make students active participants in class (bi1, hi1). Interestingly, this aspect of teaching emerged as a topic in the interviews at one of the schools, where they had recently changed to a long-lesson format with only one lesson per week, each lesson being 240 minutes.

The biology teachers spoke about their concern for students' successful conceptualization of content. If they sensed that the students could not follow what they were talking about they would take action in different ways. Whereas one biology teacher would provide the terminology in Swedish (bi3), another would try to explain in English before providing the Swedish word (bi2). There were also examples of biology teachers making word lists for the students to study (bi4), and of providing opportunities to check their understanding of concepts through digital tools (bi4).

The biology teachers could see students' progression in their subject from one year to another. Whereas the biology students in year one were found to be silent in class, in the second year they would speak more in class (bi3), and in their oral presentations the teacher could see that "they [the students] knew what they were talking about" (bi1). In reflecting on the reasons for the stages in these 'developmental sequences', the teachers commented that "perhaps the students know me a little bit better now" (bi3) and that the second year students were more experienced in using the language [English] combined with the study of biology (bi1).

The history teachers did not only account for planning of teaching and learning with regard to several modes for the entire group, but also with regard to individual students:

It is part of ... having different tasks depending on which student it is. Sometimes they might say 'I can't write more now, I can't write one more essay'. Then my response can be 
'Use exactly these questions, and make a recording where you are talking about this, and send it to me (hi3)

Adaptation of language use could also vary with students groups from one year to another. In the first interview with history teacher 3, the teacher claimed to be very strict with the use of English in history class whereas in the follow-up interview the year after the teacher spoke of the benefit of bilingual practices:

If they [the students] are talking to me in Swedish, I have promised them that on coming here to study at this school I will speak English with them, and therefore I do it. ... as they want to discuss assignments with me in Swedish, then I answer in English, because that is what this school is (hi3).

It depends on the group of students... You have to adapt your teaching to the group of students ... I have group of first year students this year. This year I have materials in both English and Swedish... If they feel more secure with regard to Swedish, they can study the English material later... We work parallel with the two languages ... We have to reach this level (hi3)

The results suggest that the teacher's practices had changed from one year to another. Whereas $\mathrm{s} / \mathrm{he}$ in the first year claimed to be teaching basically through 100\% English, a year later the linguistic practices were different. The new students needed these bilingual practices to be able to reach the goals of the course, the teacher claimed.

One of the history teachers spoke about the necessity of being consistent with language use in class, a practice the teacher had developed in response to students: "They [The students] do not want me to mix languages. If we are into one language, then we should stick to this language" (hi2). Instead of randomly switching between languages, bringing in a Swedish or English word every now and then, the students in this history class wanted their teacher to use one language at a time, the teacher reported. Therefore, the teacher was now experimenting with various practices including the use of Swedish on some occasions and the use of English on other occasions, making clear that the students should know in advance when which language was going to be used.

One of the biology teachers was not keen on pushing students to participate actively in class: "I don't think that I have to demand of students to account for what they know during the lessons" (bi1). Acknowledging that some students would be anxious to ask questions in class, irrespective of the use of language in the teaching situation, the teacher provided them with opportunities to ask questions after class:

At the same time I know that there are several students who do not dare to ask. But they might not have dared to ask in Swedish either. If there are questions that students do not want to put forward in class. I tell them 'I stay here if you want to ask questions' (bi1)

Somewhat differently, in history class the students got plenty of opportunities to formulate themselves by means of different modes. It could be orally in class in the form of role play, through essay writing in class or through home exams. The motivation to this choice of teaching methods is that it challenging to study content through a foreign language: "This is about being 
taught through another language [than the first language]. Therefore, you have to make use of a whole range of working methods in class" (hi3). The teacher used a meta-cognitive perspective to address the challenging task of learning and teaching content through a foreign/second language. In the above example, the teacher was taking turns between the teacher perspective and the student perspective to explain and motivate the choices that were made.

The terminology they are, sort of, vocabulary and things like that they are good at. They do ask a lot, though. This is when they are working with their essays... (hi3)

The history teacher had noticed that it was on the occasions when the students had to formulate themselves in writing that they started to become aware of, and be particular about, their language use. It was not until the students had to explain what they meant in writing that they started to question and problematize their understanding of certain concepts and terms.

\section{Discussion}

In the following, the results of the study will be discussed with regard to three aspects of languaging; linguistic, communicative and content aspects. Thereafter, the section concludes with a discussion of results in relation CLIL teaching literacy, a concept developed by the researcher.

\subsection{Languaging - the linguistic aspect}

Findings show that the CLIL biology and history teachers' cognitions treated language as a code. References to language were made at the lexical level. More specifically, the utterances made by the CLIL teachers had to do with subject-specific language (Lindberg, 2006). Especially in the biology teachers' descriptions of, and motivations to, language use, language as a code appeared important. The biology teachers' cognitions seemed to have a bearing on the syllabus for biology, with its focus on "knowledge of biological concepts" (Lgy11, Biology).

In fact, against the background of scientific discourse (Halliday \& Martin, 2004) and theory on the language of schooling (Schleppergrell, 2004), it could be argued that there is more to be done with regard to the linguistic aspect of languaging in the CLIL classroom. As previously pointed out, not necessarily should the content teacher engage in all the tasks of a language teacher (Coyle, Hood \& Marsh, 2010), but the school subject literacy dimension would need to be attended to. In practice, this could mean that the teacher makes efforts to create semantic fields in their teaching, that students' attention is being directed to word formation rules or that nominal phrases are highlighted and commented on. In their pre-planning of lessons, not only content area but also language could be systematically planned for (Nixon 2001), as a means of designed scaffolding (Gibbons, 2009). In this respect, Lindberg's distinction between colloquial language, school-related language and subject-specific terminology could prove a useful structure for defining, and using, language in different contexts related to the school subject.

\subsection{Languaging - the communicative aspect}

Without exception, the history teachers' narratives were concerned with planning their teaching of history through several modes, in a multimodal way. They took into consideration the affordance of two languages as well as access to other semiotic resources, e.g. film and role play, for application in the content classroom. Thus, it could be claimed that the history teachers 
interviewed in this study demonstrate awareness of the benefits of an interactive approach to teaching and learning, making it possible for students not only to receive input, but also to be productive in their learning processes through various modes and formats. The history teachers' cognitions could be related to the syllabus for history with its emphasis on students' engagement in literacy practices to "explain and visualize historical developmental processes" (Lgy11, p. 66).

In the new curriculum documents for biology, activities which involve extended and advanced use of language are also to be found, the requirements for students being to develop ability to "critically assess" and to "discuss and present analyses and conclusions" (Lgy11, Biology). Somewhat differently, however, the biology teachers' reported dilemmas with regard to spoken dialogue in the English-medium classroom (bi1, bi3). These results resonate with earlier research in the Swedish school context. Lim Falk's empirical studies in CLIL classrooms in the early 2000s resulted in similar findings with regard to questions - or lack of students' questions - in biology class (Lim Falk, 2002, 2008). It is worthwhile pondering whether this is a phenomenon that has to do with the English-medium teaching mode, or whether it should be related to subject-specific teaching literacies within the biology subject?

Clearly, the issue of talking science as a mode for the development of science teaching is not new (Lemke, 2000). Still, in empirical investigations with teachers and learners in practice, it re-occurs as a problematic issue. Potentially, co-working practices between language teachers and biology teachers at the school could_facilitate the learning process for the students in this respect.

\subsection{Languaging - the content aspect}

Languaging in terms of content can be understood at three levels, the lexical word level, the genre level and the discourse level. Results of this study show that the content teachers first and foremost reason with regard to the lexical level. Their concern is targeted toward making the subject content comprehensible to the student, and in this pursuit they focus on subject-specific terminology. They see it as their task to explain to students what certain concepts mean, and how concepts are related to another.

In the analysis of the teachers' utterances on language choice and language use a sort of polarity emerged. With subject-specific language and colloquial language at one end, the teachers were on safe ground, according to their reports. At the other end, with regard to the generic academic language, the school-related language (Lindberg, 2006), the teachers reported on difficulties in formulating themselves, especially in those situations in the content classroom when they needed to make longer explanations in English (bi3).

Most commonly, the biology teachers spoke of their translation of concepts, of their practices when it came to use of language in terms of definition, description and explanation of terminology. One exception was biology teacher 4 , who claimed that it is not the terms themselves that are difficult for the students to comprehend, it is the content area as such, no matter what language is being used (bi 4). History teacher 3 held a similar view: "The terminology they are, sort of, vocabulary and things like that they are good at. They do ask a lot, though. This is when they are working with their essays..." (hi3).

To conclude, knowledge of subject-specific terminology as a starting point, the content teachers could be considered to be excellent language users and teachers. With regard to communication, especially in genres, involving both subject-specific terminology and the teachers' ability to act in extended speech and dialogue, also having to draw on their knowledge of generic academic language in the bilingual space, appeared to have limitations. With 
structured opportunities to study and practice such dialogues in relevant contexts, with colleagues who also work in bilingual programs, the content teachers could develop their teaching literacy.

\subsection{CLIL teaching literacy}

In the analyses of the interview material, the teachers were found to be reflective practitioners (Argyris \& Schön, 1974). It became clear that they continuously reflected on their planning, actions, and the effect of their actions. The more experienced teachers had tried out different practices throughout the years, and had settled for certain linguistic practices they knew to be functional in their content classroom, e.g. reporting that "This is my strategy" (bi2). These practices were not treated as matters of uncertainty. In contrast, they appeared to be results of reflected, professional, decision-making. Still, however, the teachers were interested to know more about the effects of various practices at a larger scale: "This English we use here, how effective is it, really?" (bi3).

Interestingly, the experienced biology teacher who was relatively new to CLIL, spoke with assertiveness about the use of subject-specific terminology. The content teacher knew with precision the terms for concise description and explanation in the two languages. As regards using terminology in spontaneous, extended, dialogic speech, however, the teacher was not at ease. Not surprisingly, the content teacher who taught through the foreign language was in possession of a considerable knowledge basis in terms of terminology as part of a particular social context: the genre and discourse knowledge was thorough (Martin, 1985). However, the pedagogic content knowledge (Schulman, 1986) that the teacher was in the process of developing, however, the bilingual one, was a current concern: "it is not so easy, making ad-hoc explanations" (bi3). Assumedly, in the light of long-term experience of teaching, the teacher's aim was to soon reach the ability to teach with the same ease in the bilingual mode as through one language.

The new teachers were eager to talk about their efforts, emphasizing how much time and effort teaching through a foreign languages initially requires. Clearly, as the teachers referred to access to existing study materials, and design of own materials, they were focused on their own use of language. At the same time, however, they were attending to the students' response to teacher language. There appeared to be an ongoing dialogue between teachers' and students on dynamics of language use, the teachers aiming to adapt their language use both to student groups and individual students.

The experienced history teacher who was relatively new in CLIL teaching, reported from current experiments with the linguistic arrangement for history class. In response to students, the teacher had stopped applying random translanguaging practices in the classroom. As the students had found the teachers' moves between the languages too frequent and too unpredictable, the teacher was trying to find a balanced structure for the bilingual turns. The teacher was aiming for means of 'pedagogic translanguaging' (Yoxsimer Paulsrud, 2014).

Indeed, the results of this study show how constantly concerned teachers were with finding suitable practices for their communication with the students, and with designing optimal conditions for students' learning of their subject. Here, teaching literacy emerges as a useful concept for understanding teachers' cognitions and teaching practices. As is the case with the term literacy since its origin, it starts to exist and has the potential to develop as soon as it is being activated (Heath \& Street, 2008). Consequently, in this study we can find CLIL teaching 
literacy to be a suitable term for understanding and interpreting teachers' motivations to language use and teaching in the content classroom.

\section{$7 \quad$ Concluding remarks}

This study has documented content teachers' reflections on language practices in CLIL. Considering the small-scale format of the study, it does not claim to provide results or recommendations that can be applicable at a general level. However, insight into only a few CLIL teachers' teaching literacy could still be of value to other teachers, or to researchers interested in developing similar studies in their educational contexts.

A final recommendation is for school leaders: do plan for opportunities for your teachers from content-based school subjects and language-based school subjects to engage in discussion with each other, exchanging experience and learning from each other's expertise when it comes to supporting students' learning in bilingual spaces. As shown in this study there is potentially much to be gained from such encounters of expertise. CLIL seems to be conducive to professional development.

\section{Acknowledgements}

Hereby I would like to express my gratitude to the reflective practitioners who participated in this study. Without your sharing of your teaching literacy, this study would not have come into being. Also, I would like to thank the Swedish Research Council and the Department of Language Education, Stockholm University, for financial support.

\section{References}

Airey, J. (2013). Disciplinary literacy. In: Lundqvist, E., Säljö, R. \& Östman, L. Scientific Literacy. Teori och praktik. Malmö: Gleerups, pp. 41-57.

Argyris, C. \& Schön, D. A. (1974). The Reflective Practitioner. How Professionals Think in Action. San Francisco, CA: Jossey-Bass Inc. Publishers.

Borg, S. (2006). Teacher cognition and language education. London: Continuum.

Brinkmann, (2009). Den kvalitativa forskningsintervjun. Lund: Studentlitteratur.

Bryman, A. (2013). Samhällsvetenskapliga metoder. Malmö: Liber.

Coyle, D., Hood, P. \& Marsh, D. (2010). CLIL. Content and language integrated learning. Cambridge, UK: Cambridge University Press.

Cross, R. (2016). Language and content 'integration': the affordances of additional languages as a tool within a single curriculum space. Journals of Curriculum Studies 48(3), 388-408.

Cummins, J. (1979). Cognitive/academic language proficiency, linguistic interdependence, the optimum age and some other matters. Working papers on Bilingualism, No. 19, 121-129.

Dalton-Puffer, C. (2011). Content-and-Language Integrated Learning: From Practice to Principles? Annual Review of Applied Linguistics, 182-204.

García, O. (2009). Bilingual Education in the $21^{\text {st }}$ Century. A Global Perspective. Chichester: Wiley-Blackwell.

García, O. (2011). Pedagogies and Practices in Multilingual Classrooms: Singularities and Pluralities. The Modern Language Journal, 385-400.

Gibbons, P. (2009). English Learners, Academic Literary and Thinking: Learning in the Challenge Zone. Portsmouth: Heinemann.

Halliday, M.A.K. (2004). The Language of Science. London: Routledge. 
Halliday, M.A.K. \& Matthiessen, C. (2004). An Introduction to Functional Grammar. London: Arnold.

Heath, S. B. \& Street, B.V. with Molly Mills (2008). Ethnography. Approaches to Language and Literacy Research. New York: Teachers' College Press.

Lemke, J. (2000). Multimedia demands of the scientific curriculum. Linguistics and Education $10(3), 247-272$.

Leung, C. (2005). Language and content in bilingual education. Linguistics and Education, 238252.

Lim Falk, M. (2002). Språk- och innehållsintegrerad inlärning och undervisning i praktiken: meningsfull språkträning? (MINS.51). Stockholms universitet: Institutionen för nordiska språk.

Lim Falk, M. (2008). Svenska i engelskspråkig miljö. Ämnesrelaterat språkbruk i två gymnasieklasser. Doktorsavhandling. Stockholm: Stockholms universitets förlag.

Lindberg, I. (2006). Bedömning av skolrelaterat ordförråd. In: Olofsson, M. (ed.) Symposium 2006. Stockholm: Stockholms universitets förlag, 83-107.

Lundahl, B. (2010). Engelsk språkdidaktik. Lund: Studentlitteratur.

Martin, J. R. (1985). Process and Text: Two aspects of semiosis. In J.D. Benson \& W.S. Greaves (Eds.) Systemic Perspectives on Discourse, Vol. 1: Selected Theoretical Papers from the $9^{\text {th }}$ International Systemic Workshop. Amsterdam: John Benjamins, 248-274.

Nikula, T., Dalton-Puffer, D. \& Llinares, A. (2013). CLIL classroom discourse. Research from Europe. Journal of Immersion and Content-Based Language Education 1(1), 71-100.

Nixon, J. (2001). Integrating the language with the teaching of content. In: Ferm, R. \& Malmberg, P. Språkboken. En antologi om språkundervisning och språkinlärning. Stockholm: Skolverket.

Richards, K. (2009). Interviews. In: Heigham, J. \& Croker, A. (eds). Qualitative Research in Applied Linguistics. A Practical Introduction, 182-199.

Sandberg, Y. (2015). CLIL interaction challenges: Genre and translanguaging as pedagogic tools? In: Gitsaki, C. \& Alexiou, T. (eds). Current Issues in Second/Foreign Language Teaching and Teacher Development: Research and Practice, 212-227.

Shulman, L. (1986). Those Who Understand: Knowledge Growth in Teaching. Educational Researcher 15(2), 4-14.

Schüllerqvist, B. (2012). De samhällsvetenskapliga ämnenas didaktik. En skandinavisk översikt. I: Ämnesdidaktisk komparation. Länder, ämnen, teorier, metoder, frågor och resultat. (pp. 25-43). Karlstad: Universitetstryckeriet.

Skolverket (2011). Läroplan, examensmål och gymnasiegemensamma ämnen för gymnasieskola 2011. Stockholm: Fritzes.

Skolverket (1994). Läroplan för de frivilliga skolformerna Lpf 94. Stockholm: Fritzes.

Sylvén, L.K. (2013). CLIL in Sweden - why does it not work? A metaperspective on CLIL across contexts in Europe. International Journal of Bilingual Education and Bilingualism 16(3), 301-320.

Tornberg, U. (2009). Språkdidaktik. Malmö: Gleerups.

Yoxsimer Paulsrud, B. (2014). English-medium instruction in Sweden: Perspectives and practices in two Swedish upper secondary schools. Doctoral thesis. Stockholm: Stockholm University. 